\title{
Wonosobo Regulation No. 3 of 2014 on Regarding Regional Organization to Achieve Good Governance
}

\begin{abstract}
Ahmad Faqih $^{1}$ and Widayati ${ }^{2}$
Abstract. The problems examined in this study is how effective and efficient arrangement of the bureaucracy of encouraging good governance, whether Wonosobo Regency Regulation No. 3 of 2014 is able to create efficiency and effectiveness of governance in Wonosobo, What are the obstacles and the solution? The research is a qualitative study using sociological juridical approach. Data collection methods used were observation, interview, and documentation. Then analyzed by qualitative analysis methods in order to produce a complete understanding. From the results of this research study concluded that There are two causes of delays in the implementation of the Regulation No. 3 of 2014 on the WTO technical factorsinvolves the placement of a new position at the WTO and non-technical factorsrelated to "political decision" by the government. The effectiveness of the performance of the bureaucracy as the implications of the implementation of the Regulation No. 3 of 2014 on OPD influenced by fundamental structural changes in regional organizations through the establishment of Regulation No. 3 of 2014 on the WTO which replaced Regulation No. 2 Of 2008 on Regional Government Affairs Wonosobo. The impact was to reduce $268 / 37 \%$ structural office with details of the total original echelon becomes 728 to 460 echelon.Downsizing and demotions office structure certainly affects the quality improvement of bureaucratic performance in delivering public services more effective, efficient in carrying out extensive local autonomy, real and responsible, Thus, thethe concept of streamlining the structure of the program structuring and management of bureaucratic apparatus becomes linear simultaneously.

Keywords: Regional Organization; Good Governance.
\end{abstract}

\section{Introduction}

Efforts to build good governance through bureaucratic reforms have also been initiated by local governments Wonosobo by creating Regional Regulation (Perda) Wonosobo District No. 3 of 2014 concerning the regional Organization (WTO) The District Government as a strategic policy at the same time a new breakthrough in efforts to manage governance good (good Governance)in order to realizing the government bureaucracy more functional areas in the implementation of public service duties. Arrangement in all aspects of management bureaucracy (bureaucratic reform), among others, need to be supported by the institutional structure of the appropriate regional organizations and the proper function of size (right sizing), However, the implementation of the Regulation No. 3 of 2014 on the WTO had been delayed for one tahunsejak set at January 30, 2014 and enacted in Wonosobo on 10 April 2014then just held on 17 April 2015, There are two factors causing delay in the implementation of the regulation ie technical factorsinvolves the placement of a new position at the WTO after experiencing downsizing or demotion office and non-

\footnotetext{
${ }^{1}$ Students Master Program (S2) of Law UNISSULA email: ahmadfaqih185@gmail.com

${ }^{2}$ Lecturer of Faculty of Law UNISSULA
} 
technical factors related to "political decision" of the government on who will occupy the positions at each level of the position in the new OPD.

Other than that, The fundamental consequences on the implementation of Regulation No. 3 of 2014 on the WTO is to require the merit system at the organization structure of the slim governance so fat governmental organizations in several Unit perangkan Regions must undergo deletion, merging of two departments into one department or office turned into offices or section, so that at the beginning of its implementation, the regulation alsoraises the pros and cons, especially among officials of Echelon II. The issue arises when the initial structural positions 261 and 268 deleted domesi structural officer. Even the judicial review carried out some officials even though the Supreme Court ultimately rejected.

By law that have been formulated since 2010, the other side is a step towards directing service in the form of services in an inclusive, open and objective and integrated in view of the public in need of services are clear, so that the target fulfillment of work by the device area and fulfillment of the rights for the community can be realized and the balance (balance) in Regulation No. 3 In 2014, the entire bureaucratic officials will remain functional even though some officials employee will suffer demotion and shifts. Furthermore, the commitment to run Regulation No. 3 of 2014 on the WTO. The District Government a major effort to carry out the reform agenda of the bureaucracy, which not only provide public services that are effective, efficient and accountable, but also provide real-time record in appreciating the broad local autonomy, real and responsible on the one hand and realization of professional work behavior in providing services to public by State apparatus on the other side.

Based on the above explanation, this study intends to examine the extent to which the implementation and identify problems and hinder the implementation of Regulation No. 3 of 2014 concerning the regional Organization The District Government with a view to encourage the performance of local governments in order to implement the bureaucratic reform agenda according to provisions of the regulation in order to realize good governance. So we writers interested in discussing scientific research or entitled Implementation Wonosobo Regency Regulation No. 3 of 2014 on the organization of the Region to Achieve Good Governance.

Based on the above background, formulation of the problem which will be examined are: Does the efficiency and effectiveness of bureaucratic arrangement will promote the establishment of good governance ?; Are Structuring the regional Organization of Wonosobo based on Local Regulation No.3 of 2014 can create efficiency and effectiveness of government administration in Wonosobo regency ?; What barriers and solutions so that local regulations implementing number 3 of 2014 can realize good governance in Wonosobo?

\section{Research Methods}

Method The approach used in this study is a sociological juridical approach, ie where in the face of the problems addressed by the regulations applicable then connected with the realities that occur in the field. 
Qualitative research is descriptive analysis that is used to locate, describe, and explain the quality or features of the social influences that can not be described, measured or described through quantitative approach.

\section{Result And Discussion}

\subsection{Bureaucratic Structuring The Efficiency And Effectiveness Of Encouraging Good Governance}

That's creating a bureaucracy that is efficient, effective in order to support democratic governance and national economy, the government should implement the strategy of institutional reform of the bureaucracy which has the purpose of 1) strengthening the institutional reform of the bureaucracy, 2) improve public services by implementing management based on performance, 3 ) build the capacity of the state apparatus to create maximum public services, and 4) organization and personnel professional SDA, apolitikal, neutral, transparent, and accountable. ${ }^{3}$

The main key to understand good governance is an understanding of the principles in it. Starting from these principles will obtain a performance benchmark government. The merits of government NSU rated when he had been in contact with all nsure the principles of good governance, namely Partition Society (Participation), Rule rule of law, Transparency, Caring for Stakeholder / World Enterprises, Oriented Consensus, Equality, Effectiveness and Efficiency, Accountability and Strategic Vision. ${ }^{4}$

Relating to the standard process and as well as results, understanding and development of Good Governance through bureaucratic reform should include all members of the government to be able to move quickly, synergistic, do not collide with each other, gain the support of the people and in spite of the movement anarchist that can inhibit the process development. Indicators of success of good governance, if the development can be done with very minimal cost to the ideals of welfare and prosperity, show the results of the people's economic ability indicator increases, welfare spiritualisasinya increased sense of security, calm, happy and full of peace. $^{5}$

\subsection{Arrangement of regional organizations in Wonosobo based on Local Regulation No. 3 of 2014 to create efficiency and effectiveness of the government in Wonosobo}

One disadvantage of Organizational Structure and Work Procedure of the Local Government (SOTK) is that everything must be regulated in accordance with the interests of a political nature between the executive and the legislature, and usually if your organization grows bigger there will be a lot of bureaucratic obstacles in it. Moreover, the existence of the organizational structure and before regulated Perda No. 3 of 2014 on bureaucratic structures are too "fat". The resulting structure that fat does not run effectively and efficiently. Many civil officials Wonosobo regency government environments that do not have an ideal organizational culture. In fact,

\footnotetext{
${ }^{3}$ Miftah Thoha 2007 Birokrasi Dan Politik Di Indonesia RajaGrafindo Persada Jakarta p. 18

${ }^{4}$ Drs. Made Supartawan MM Pengertian Prinsip dan Penerapan Good Governance di Indonesia accessible fromhttps://humassetda.bulelengkab.go.id/artikel/pengertian-prinsip-dan-penerapan-goodgovernance-di-indonesia-99 On January 52018 11:20

${ }^{5}$ Asep Saepuloh Tarsono 2001 Pendidikan Kewarganegaraan Batic Press Bandung p. 175
} 
according to Tri Antoro, in addition to the structure of fat there is overlap between the duties of the regional organization.

"The weakness of the organizational structure and regulation, local government before implementation Perda No. 3 of 2014 concerning, among others, his organization is too "fat". Some consist of several structures function. While positions that are not rich, there overlapping between OPD, resulting in high operating costs and bureaucratic system rambling. "6

Besides too fat structure, weakness SOTK before implementation Perda No. 3 of 2014 about as well as the uneven division of tasks between each other, they overlap with each other duties and operational costs are too high. ${ }^{7}$ In the aspect of the organizational structure and the structure of the fat and less reflective of effectiveness and efficiency, so analysis positions and workload analysis should be carried out comprehensively in each SKPD. It is intended that Wonosobo really ideally suited to the needs of the organization. "... the reference SOTK is job analysis and workload analysis should be done comprehensively in every SKPD to future results of the analysis actually be a reference organizational structure and ideal for and according to the needs of local government organizations to support employee performance effectively and efficiently in accordance with the spirit of the desired reform of the bureaucracy." 8

In Act No. 5 of 2014 on Reform of Civil State mentioned that to realize the apparatus of civil state as part of the reform of the bureaucracy, should be set apparatus civilian state as a profession has an obligation to manage and develop themselves and are obliged to account for its performance and apply the merit principle in the implementation apparatus management civilian state.

The law citations that one of the principles underlying the governance embody that ideal is the existence of the merit principle in the implementation of the civilian apparatus management nation. In Article 1, paragraph 22 of Law ASN explained that the merit system is the policy and management of ASNs based on qualifications, competence, and fair and reasonable performance with regardless of their political background, race, color, religion, origin, gender, marital status, age, or disability.

Guarantee the implementation of the merit system is the responsibility of the institution KASN. KASN is a non-structural institution that is independent and free from political intervention to create a professional ASN Employees and performers, providing services in a fair and neutral, as well as being gluten and unifying the objective of ensuring the realization of the merit system in the policy and management of ASN.

Thus it is clear that regulation of Wonosobo No. 3 of 2014 on regulations implementing the WTO is rapidly Law ASN in creating bureaucratic reform agenda. The constraints that arise due to changes in the structure is a reasonable problem that requires a process of adaptation. In turn, the system will force the entire bureaucracy and employees to carry out its performance in accordance with Regulation No. 3 of 2014 on the WTO.

\footnotetext{
${ }^{6}$ The results of the interview dated February 82018 by Drs. Tri Antoro M.Si

${ }^{7}$ The results of the interview dated February 32018 with lip Syarifudin SH

${ }^{8}$ The results of the interview dated February 72018 by Afif Nur Hidayat S.Ag
} 


\subsection{Obstacles and solutions for the implementation of regulation No. 3 of 2014 can realize good governance?}

One purpose of establishing the organizational structure and working procedures of governance is in order to encourage the implementation of bureaucratic reform as a necessity role in efforts to achieve good governance. However, the structure only as a tool only for filling the position must be followed up with competency-based and not based on like and dis-like so that the two must work together to achieve the primary goal of Good Governance. In addition, the organizational structure and performance efectiveness in local governments as a result of this regulation is richer functionality, so it is encouraging the growth of the effective functioning of the organization. With the concrete organizational duties, also encourage the establishment of a responsive government.

Analysis connected the effectiveness the performance of the organizational structure and working procedures of Wonosobo regency administration by Regulation No. 3 of 2014 on the WTO can be summed in three main outcomes namely,changes in the number of regional organizations, apparatuses and device performance management area.

\subsubsection{Barriers to implementation of the regulation number 3 of 2014 in realizing good governance}

Since the adoption of Regulation No. 3 of 2014 on the WTO, the performance of the bureaucracy is running as it should. Although it did during the first 2 months or less for a lot of personal displacement, the State Civil Apparatus must make adjustments and learn the tasks at a new position." ${ }^{9}$

Nevertheless, there are still obstacles that must be evaluated and addressed. According lip Syarifudin, there are two constraints: 1) The problems in understanding each tuposki OPD; 2) Employees who work in the respective almost not understand there is even inconsistent with the educational background and competency. ${ }^{10}$

\subsubsection{The solution to the obstacles implementing regulation No. 3 of 2014 can realize good governance}

Fundamental changes in the organization of the government district as stipulated in Act No. 23 of 2014, on local government changes the position of the sub-district includes the device of the district / city and sub-district is implementing part of government affairs under the authority of the Regent / Major. Subdistrict given wider powers to improve services to the public.The effectiveness of the performance of the bureaucracy as the implications of the implementation of the Regulation No. 3 of 2014 on is dependent on a fundamental structural change in the institutional structure of the appropriate regional organizations and the proper function of size (right sizing) that the estuary will lead to efficiency (down sizing). Implications from the right towards the down sizing sizing outline is through the establishment of the new regulations Regulation No. 3 of 2014 about which replaces the old regulation Wonosobo District Regulation No. 2 Of 2008 on Regional Government Affairs

\footnotetext{
${ }^{9}$ The results of the interview date February 4th 2018 with Suwondo Yudhistiro S.Sos.I

${ }^{10}$ The results of the interview dated February 32018 with lip Syarifudin SH
} 
Wonosobo regency with the number and the number of work units that undergo changes in it can be seen in the following table:

The amount and number of work units that undergo changes based on by Act No. 2 Of 2008 concerning the UPD and by Act No. 3 of 2014 on the WTO.

\begin{tabular}{|l|c|c|c|}
\hline \multirow{2}{*}{ Work unit } & \multicolumn{2}{|c|}{ Changes in Number of OPD } & \multirow{2}{*}{+ - } \\
\cline { 2 - 3 } & By Act No. 2/2008 & By Act No. 3/2014 & \\
\hline Expert staff & 5 & 2 & -3 \\
\hline assistant & 3 & 3 & - \\
\hline The section on Setda & 9 & 9 & - \\
\hline Parliament Secretariat Section & 3 & 2 & -1 \\
\hline Agency and Inspectorate & 6 & 3 & -3 \\
\hline Service & 14 & 7 & -7 \\
\hline Office & 5 & 9 & +4 \\
\hline BLUDs & 3 & 3 & - \\
\hline Districts & 15 & 15 & - \\
\hline Urban Village & 29 & 29 & - \\
\hline
\end{tabular}

Source: The Organization and Civil Regional Secretariat Wonosobo

Based on the amount or number of units of work that are changing by Regulation Wonosobo No. 2 Of 2008 on Regional Government Affairs and Local Wonosobo regency WonosoboNo. 3 In 2014, as in the table above, the Regulation No. 3 of 2014 on reduced $268 / 37 \%$ number of structural positions.

Old and New Changes Position Based on Echelon

\begin{tabular}{|c|c|c|c|}
\hline \multirow{2}{*}{ Echelon } & \multicolumn{2}{|c|}{ Change } & \multirow{2}{*}{$+/-$} \\
\cline { 2 - 3 } & By Act No. 2/2008 & By Act No. 3/2014 & \\
\hline II & 1 & 1 & - \\
\hline III B & 29 & 18 & 11 \\
\hline III B & 58 & 53 & 5 \\
\hline IV A & 31 & 51 & 30 \\
\hline IV B & 175 & 250 & 134 \\
\hline Total & 728 & 87 & 88 \\
\hline
\end{tabular}

Source: The Organization and Civil Regional Secretariat Wonosobo

"This is the concept of simplification and streamlining structures simultansinya with the Setup program and administrative bureaucratic apparatus becomes linear and simultaneously. Thus, the impact of its positive impact on the working culture system repair mechanisms and performance will show the effectiveness and productivity of public services better. "11

\footnotetext{
${ }^{11}$ The results of the interview date February 142018 with Kholiq Arif M.Si
} 
With the implementation of Regulation No. 3 of 2014 concerning the of 2015, it is expected to be realized implementation of governance clean and dignified, efficient and effective, responsive and accountable, act and sided with the interests of the community, and be able to maintain a harmonious partnership through a process of interaction symbiotic dynamic and constructive between OPD, government and society and relations between various other groups which have the same interest in achieving good governance.

\section{Closing}

\subsection{Conclusion}

Implementation of the Regulation No. 3 of 2014 on the Organization of Local Government District Government had been delayed for one since January 30, 2014 and enacted in Wonosobo on 10 April 2014 then just carried on 17 April 2015, There are two causes that the implementation of WTO legislation that technical factorsinvolves the placement of a new position at the WTO and non-technical factors related to "political decision" by the government.

- The effectiveness of the performance of the bureaucracy as the implications of the implementation of the Regulation No. 3 of 2014 on OPD influenced by fundamental structural changes in regional organizations through the establishment of a new regulation (Regulation No. 3 of 2014 on OPD) which replaces the old regulation (Regulation No. 2 of 2008 on Regional Government Affairs Wonosobo). The impact was to reduce $268 / 37 \%$ structural position echelon with the details of the original total to 460728 into the echelon.

- The efficiency of the implementation of the regulation No. 3 of 2014 on the WTO to the regional budget was significant because it can reduce the shopping areas of Rp. 3.944.756.00,00 on obligatory and reduce the amount of Rp. 12,368,231,990.00 at choice. While affairs obligatory increase in expenditure on affairs and selection of Rp. 231,934,545,996.00 of the total budget earmarked for the change of affairs that is focused on improving the quality of local device performance and service to the community more effective, efficient and accountable in implementing broad local autonomy, real and responsible,

- Evaluation needs to be done in the implementation of the Regulation No. 3 of 2014 on the WTO are:

- The development of an institutional as well as mapping and identification of matters that fall under the authority of each of the WTO is based on the mapping of the Ministry of Interior with the Letter of the Minister of Internal Affairs issued on January 16, 2015 on the Implementation of Government Affairs after regulated Act No. 23 of 2014 on Local Government;

- Evaluation is carried by the revised PP 41 of 2007 on the new regional organization to fit or does not conflict with the rules on it;

- Evaluation is done jointly between the executive and the legislature and is oriented towards service and meeting the needs of society as a whole; 


\subsection{Suggestion}

- Regulation in order to walk in the direction of the WTO and the ultimate goal of the implementation of local government, Then the placement of structural officials need to be done in accordance with the educational background and competences so that government management is actually running effectively and efficiently.

- The evaluation of the implementation of the Regulation is done in a comprehensive manner on all elements and a task force with reference to the laws and government regulations such as the Act No. 5 of 2014 on ASN, Act No. 23 of 2014 on Regional Government, Presidential Decree No. 81 of 2010 concerning the Grand Design Reforms, Of 2010 to 2025 and other regulations.

\section{Bibliography}

[1] Dahniar Ati 2016 Dinamika Birokrasi dan Pelayanan Publik (Pengayaan Materi Administrasi Perkantoran Modern dalam Diklat Perkantoran dan PIM IV)

[2] Miftah Thoha 2007 Birokrasi Dan Politik Di Indonesia RajaGrafindo Persada Jakarta

[3] Drs. Made Supartawan MM Pengertian Prinsip dan Penerapan Good Governance di Indonesia diakses dari https://humassetda.bulelengkab.go.id/artikel/pengertian-prinsip-dan-penerapangood-governance-di-indonesia-99 pada tanggal 5 Januari 2018 pukul 11:20

[4] Asep Saepuloh Tarsono 2001 Pendidikan Kewarganegaraan Batic Press Bandung

[5] Interview date February 32018 the Head of Finance Secretariat Wonosobo regency Kardimin $\mathrm{SH}$,

[6] Interview on 3 February 2018 Parliament Secretary Wonosobo lip Syarifudin SH.

[7] interview date February 4th 2018 the Chairman of the Committee A (law and administration) Wonosobo district legislature Suwondo Yudhistiro S.Sos.I,

[8] interview date February 7th 2018 the Chairman of the Parliament of Wonosobo Afif Nur Hidayat S.Ag.

[9] Interview February 82018 Head of Government Secretariat of Wonosobo regency Drs. Tri Antoro M.Sc.

[10] interview date February 23 2018the Head of Organization and Civil Sekretairat Wonosobo regency Maria Susiawati S. Sos. MPA 